\title{
PENGARUH PDRB DAN ASET TERHADAP PENERIMAAN DAERAH SERTA IMPLIKASINYA PADA KINERJA KEUANGAN PEMERINTAH KABUPATEN/ KOTA DI JAWA TENGAH
}

\author{
Indriyani \\ AKADEMI MARITIM NUSANTARA \\ Tiara Pandansari \\ UNIVERSITAS MUHAMMADIYAH PURWOKERTO
}

\begin{abstract}
This research was conducted to obtain evidence related to the Influence of Gross Regional Domestic Product and Assets in Revenue And Their Implications On Financial Performance in Regency/ City in Central of Java. Financial performance is calculated using the fiscal capacity, fiscal decentralization ratio independence ratio , the ratio of the effectiveness and efficiency ratios. The research was conducted and located in 35 Regency / City in Central of Java, consists of 29 regency and 6 city . The data used in the form of APBD and realization APBD, Balance Sheet and GDRP in Central of Java in 2008 to 2011 . Tests performed by using regression analysis .

The results of this research indicate that GDRP have positive and significant impact on local revenues, Assets do not affect to the local revenue and Local revenue is negative and significant effect on financial performance. Testing for local revenue as variable that mediate GDRP and assets against financial performance was tested using regression analysis of variables mediating the causal step method and obtained results that did not mediate the relationship GDRP and assets with financial performance.
\end{abstract}

Keywords : GDRP, assets, local revenues, financial performance 


\section{ABSTRAK}

Penelitian ini dilakukan dengan tujuan untuk memperoleh bukti terkait dengan pengaruh PDRB dan Aset terhadap Penerimaan Daerah Serta Implikasinya Pada Kinerja Keuangan Pemerintah Kabupaten/ Kota Di Jawa Tengah.Kinerja Keuangan dihitung dengan menggunakan rasio keuangan yaitu kapasitas fiskal, rasio desentralisasi fiskal, rasio kemandirian, rasio efektivitas dan rasio efisiensi. Penelitian ini dilakukan di pemerintah kabupaten/ kota di Jawa Tengah yang berjumlah 35 kabupaten/ kota terdiri dari 29 kabupaten dan 6 kota. Data yang digunakan berupa APBD dan realisasi APBD, Laporan Realisasi Anggaran, Neraca, PDRB Kabupaten/ Kota Di Jawa Tengah tahun 2008 sampai dengan tahun 2011. Pengujian dilakukan dengan menggunakan analisis regresi.

Hasil penelitian ini menunjukkan bahwa PDRB berpengaruh positif dan signifikan terhadap penerimaan daerah, Aset tidak berpengaruh terhadap penerimaan daerah, Penerimaan Daerah berpengaruh negatif dan signifikan terhadap kinerja keuangan.Pengujian untuk variabel penerimaan daerah sebagai variabel yang memediasi PDRB dan Aset terhadap kinerja keuangan diuji menggunakan analisis regresi variabel mediasi dengan metode kausal step dan diperoleh hasil bahwa penerimaan daerah tidak memediasi hubungan PDRB dan Aset dengan kinerja keuangan.

Kata kunci : PDRB, Aset, Penerimaan Daerah, Kinerja Keuangan

\section{PENDAHULUAN}

Pemberlakuan otonomi daerah di Indonesia dimulai sejak dikeluarkannya UU No 22 tahun 1999 yang kemudian diperbaharui oleh UU No 32 tahun 2004 tentang Pemerintah Daerah, namun kenyataannya sampai dengan saat ini pembangunan Indonesia khususnya di Pulau Jawa masih belum merata. Menurut Badan Pusat Statistik (BPS) Provinsi Jawa Tengah memiliki Produk Domestik Regional Bruto (PDRB) per kapita terendah dibandingkan 5 provinsi lain yaitu: DKI Jakarta, Jawa Timur, Jawa Barat, Banten dan Daerah Istimewa Yogyakarta.

Masih rendahnya Asset dan PDRB Per kapita ini terjadi diduga karena belum optimalnya Pemerintah Daerah dalam mengelola potensi yang dimiliki oleh masing-masing daerah, karena menurut Sukirno (1978) menyatakan bahwa PDRB menggambarkan kemampuan daerah dalam mengelola sumber daya pembangunan yang dimilikinya, oleh karena itu besaran PDRB setiap daerah bervariasi sesuai dengan potensi yang dimiliki dan faktor produksi masingmasing daerah. Melihat fenomena yang ada, Hidayat (2009) menyatakan bahwa dalam era desentralisasi, pemerintah daerah dituntut mampu berkompetisi memberikan fasilitas kepada tiap sektor untuk mendorong peningkatan PDRB dan mengelola aset yang dimilikinya dalam meningkatkan penerimaan daerah yang pada akhirnya memberikan dampak positif terhadap kinerja keuangan. Peningkatan PDRB dan aset dapat dilakukan Pemerintah Daerah melalui PAD dan DBH yang merupakan bagian PDRB yang diambil pemerintah untuk penyediaan barang dan jasa bagi kepentingan publik 
Penelitian Sularso dan Restianto (2011) menunjukkan bahwa sampai dengan tahun 2009, kinerja keuangan kabupaten/kota di Jawa Tengah dijelaskan sebagai berikut: rerata derajat desentralisasi sebesar $9 \%$, rerata rasio kemandirian keuangan sebesar $10 \%$, rerata rasio efektivitas PAD sebesar $117 \%$, rerata rasio derajat kontribusi BUMD hanya $4 \%$, rerata alokasi belanja modal sebesar $21 \%$. Melihat rerata alokasi belanja modal provinsi Jateng hanya $21 \%$ masih dibawah rerata nasional sebesar $28,8 \%$, sehingga hal ini menunjukkan kinerja keuangan pemerintah daerah di Jawa Tengah yang masih belum baik.

Pemerintah Daerah sebagai pihak yang diserahi tugas menjalankan roda pemerintahan, pembangunan dan pelayanan masyarakat wajib menyampaikan laporan pertanggung jawaban keuangan daerahnya untuk dinilai apakah pemerintah daerah berhasil menjalankan tugasnya dengan baik atau tidak. APBD dalam era otonomi daerah disusun menggunakan pendekatan kinerja yang merupakan sistem anggaran yang mengutamakan pada pencapaian hasil atau output dari input yang ditetapkan. Bastian (2006) menyatakan indikator kinerja adalah ukuran kuantitatif dan kualitatif yang menggambarkan tingkat pencapaian suatu sasaran atau tujuan yang telah ditetapkan, dengan memperhitungkan indikator masukan, keluaran, hasil, manfaat dan dampak. Publikasi indikator kinerja melayani berbagai tujuan dasar, salah satunya adalah menjamin pertanggungjawaban sektor publik.

Menurut Bastian (2006) penilaian prestasi organisasi sektor publik difokuskan pada tiga konsep dasar yaitu ekonomi mengenai input, efisiensi tentang output dan input dan efektivitas berhubungan dengan output. Beberapa rasio keuangan yang dapat digunakan untuk mengukur akuntabilitas pemerintah daerah menurut Halim (2002) yaitu rasio kemandirian keuangan daerah, rasio efektivitas dan efisien keuangan daerah, rasio aktivitas, dan rasio pertumbuhan. Hamzah (2008) meneliti kinerja keuangan dengan menggunakan rasio kemandirian, rasio efektivitas dan rasio efisiensi untuk mengukur bahwa kemandirian dan pengelolaan secara ekonomis, efektif, dan efisiensi suatu daerah atau wilayah akan dapat mendorong pertumbuhan ekonomi daerah tersebut. Pada penelitian ini menggunakan rasio keuangan yaitu kapasitas fiskal, rasio desentralisasi fiskal, rasio kemandirian, rasio efektifitas, dan rasio efisiensi.

\section{METODE PENELITIAN}

\section{Populasi dan Sampel}

Populasi dalam penelitian ini adalah Pemerintah Kabupaten/Kota di Provinsi Jawa Tengah yang berjumlah 35 kabupaten/kota terdiri dari 29 kabupaten dan 6 kota. Seluruh kabupaten/kota dijadikan sampel dalam penelitian ini

\section{Definisi Operasional Variabel}
a. Variabel Terikat
Variabel terikat dalam penelitian ini adalah kinerja keuangan. Kinerja keuangan adalah suatu ukuran kinerja yang menggunakan indikator keuangan, dalam penelitian ini kinerja keuangan diukur menggunakan rasio keuangan yaitu :
1) Kapasitas Fiskal
Nilai kapasitas fiskal diperoleh dari lampiran peraturan menteri keuangan yaitu Peraturan Menteri Keuangan Nomor 174/PMK.07/2009 Peraturan 
Menteri Keuangan No.245/PMK07/2010, PMK No.44/PMK.07/2011, serta PMK Nomor 226/PMK.07/2012.

2) Rasio Desentralisasi Fiskal

Rasio Desentralisasi Fiskal digunakan rumus sebagai berikut :

$$
\frac{P A D}{\text { Total Penerimaan Daerah }} \times 100 \%
$$

3) Rasio Kemandirian

Rasio kemandirian keuangan menggambarkan ketergantungan daerah terhadap sumber ekstern. Menurut Halim (2002), rasio kemandirian dihitung dengan rumus :

4) Rasio Efekrtivitas

$$
\frac{\text { Pendapatan Asli Daerah }}{\text { Dana Perimbangan }} \times 100 \%
$$

Rasio efektivitas menunjukkan kemampuan pemerintah daerah dalam merealisasikan pendapatan asli daerah yang direncanakan dibandingkan dengan target yang ditetapkan berdasarkan potensi riil daerah, Sularso dan Restianto (2011). Rasio efektivitas diukur dengan :

$$
\frac{\text { Realisasi Penerimaan } P A D}{\text { Target Penerimaan } P A D} \times 100 \%
$$

5) Rasio Efisiensi

Menurut Hamzah (2008), Rasio efisiensi adalah rasio yang menggambarkan perbandingan antara output dan input atau realisasi pengeluaran dengan realisasi penerimaan daerah. Semakin kecil rasio ini, maka semakin efisien, begitu pula sebaliknya. Rasio efisiensi diukur dengan:

$$
\frac{\text { Realisasi Pengeluaran }}{\text { Realisasi Penerimaan }} \times 100 \%
$$

b. Variabel bebas (independent variable)

Variabel bebas dalam penelitian ini terdiri dari Produk Domestik Regional Bruto (PDRB ) dan Aset Pemerintah Daerah

1) PDRB

PDRB adalah nilai barang dan jasa yang dihasilkan oleh suatu daerah dalam jangka waktu tertentu. PDRB yang dihitung berdasar harga berlaku. Data diperoleh dari BPS Propinsi Jawa Tengah.

2) Aset Pemerintah Daerah

Diukur dengan total aset pemerintah daerah. Data diperoleh dari Neraca pada Laporan Keuangan Pemerintah Daerah yang telah diaudit dan dikeluarkan BPK.

c. Variabel Mediasi

Variabel mediasi merupakan variabel yang berfungsi memediasi hubungan antara variabel independen dengan variabel dependen Suliyanto (2011). Variabel mediasi dalam penelitian ini adalah penerimaaan daerah. Penerimaan daerah merupakan jumlah seluruh pendapatan yang diterima oleh daerah tersebut yang berasal dari daerah itu sendiri atau pun dari pemerintah pusat, yang terdiri atas Pendapatan Asli Daerah (Pajak Daerah, 
Retribusi Daerah, Hasil Perusahaan Milik Daerah dan Hasil Pengelolaan Kekayaan Daerah yang Dipisahkan, Lain - lain PAD yang sah ), Dana Perimbangan (Bagi Hasil Pajak, Bagi Hasil Bukan Pajak/ SDA, Dana Alokasi Umum, Dana Alokasi Khusus), serta pendapatan yang diterima dari penerimaan pembiayaan daerah. Penerimaan Daerah diukur dengan satuan rupiah

\section{Model Persamaan Regresi}

a. Persamaan Model I

$$
\begin{aligned}
& \mathrm{M}=\mathrm{a}+\mathrm{b}_{1} \mathrm{X}_{1}+\mathrm{b}_{2} \mathrm{X}_{2}+\varepsilon \\
& \text { Keterangan : } \\
& \mathrm{X}_{1}=\text { PDRB } \\
& \mathrm{X}_{2}=\text { Aset Pemerintah Daerah } \\
& \quad \mathrm{M}=\text { Penerimaan Daerah } \\
& \mathrm{b}_{1}, \mathrm{~b}_{2}=\text { Koefisien regresi } \\
& \mathrm{a}=\text { konstanta } \\
& \varepsilon=\text { Error Term }
\end{aligned}
$$

b. Persamaan Model II

$$
\begin{array}{ll}
\mathrm{Y}=\mathrm{a}+\mathrm{b}_{3} \mathrm{M}+\varepsilon \\
\text { Keterangan : } \\
\mathrm{Y} \quad=\text { Kinerja Keuangan } \\
\mathrm{M} & =\text { Penerimaan Daerah } \\
\mathrm{b}_{3} & =\text { Koefisien regresi } \\
\mathrm{a} & =\text { konstanta } \\
\varepsilon & =\text { Error Term }
\end{array}
$$

c. Regresi variabel mediasi

Analisis regresi variabel mediasi dengan metode kausal step dikembangkan oleh Baron dan kenny (1986) yang dikutip oleh Suliyanto (2011). Untuk memahami pengujian mediasi menggunakan metode ini maka kita dapat menggunakan tiga persamaan regresi sebagai berikut:

$\begin{array}{ll}\text { Persamaan I } & : \mathrm{Y}=\alpha_{1}+c X \\ \text { Persamaan II } & : \mathrm{M}=\alpha_{2}+a X\end{array}$

Persamaan III $: \mathrm{Y}=\alpha_{3}+c X+b M$

Menurut Suliyanto (2011), pada uji regresi, variabel M dinyatakan sebagai variabel mediasi antara variabel $X$ terhadap $Y$ jika memenuhi kriteria sebagai berikut:

1. Jika persamaan $\mathrm{I}, \mathrm{X}$ berpengaruh signifikan terhadap $\mathrm{Y}(c \neq 0)$

2. Jika persamaan II, $X$ berpengaruh signifikan terhadap $M(a \neq 0)$

3. Jika persamaan III, M berpengaruh signifikan terhadap $Y(b \neq 0)$

Variabel $M$ dinyatakan sebagai variabel mediasi sempurna jika setelah memasukkan variabel $M$, pengaruh variabel $X$ terhadap $Y$ menurun menjadi nol $\left(c^{\prime}=0\right)$ atau pengaruh variabel $X$ terhadap $Y$ yang tadinya signifikan (sebelum memasukkan variabel $M$ ) menjadi tidak signifikan setelah memasukkan variabel $\mathrm{M}$ ke dalam model persamaan regresi. Variabel $M$ dinyatakan sebagai variabel mediasi parsial jika setelah memasukkan variabel $M$, pengaruh variabel $X$ terhadap $Y$ menurun tetapi tidak menjadi nol $\left(c^{\prime} \neq 0\right)$ atau pengaruh variabel $X$ terhadap $Y$ yang tadinya signifikan (sebelum memasukkan variabel $M$ ) menjadi tetap signifikan setelah memasukkan variabel $\mathrm{M}$ ke dalam model persamaan regresi, tetapi mengalami penurunan koefisien regresi. 


\section{HASIL PENELITIAN}

\section{A. Deskripsi Variabel Penelitian}

Populasi yang digunakan dalam penelitian ini adalah Pemerintah Kabupaten/Kota di Propinsi Jawa Tengah yang berjumlah 35 kabupaten/kota yang terdiri dari 29 kabupaten dan 6 kota. Seluruh populasi dalam penelitian dijadikan sampel penelitian. Data dalam penelitian ini diperoleh dari Badan Pusat Statistik berupa data APBD, Data Realisasi APBD dan PDRB berdasar harga berlaku. Penelitian ini juga menggunakan data yang dikeluarkan oleh BPK berupa Neraca pada Laporan Keuangan Pemerintah Daerah yang telah diaudit.

\section{Statistik Deskriptif}

Analisis Deskriptif memberikan gambaran umum mengenai data dalam penelitian ini yang meliputi nilai rerata (mean), nilai tertinggi (maximum), nilai terendah (minimum) yang diperoleh dari rerata tahun $2008-2011$.

B. Uji Asumsi Klasik

\section{Hasil Uji Normalitas}

Uji Normalitas digunakan untuk mengetahui apakah data yang diteliti terdistribusi normal atau tidak. Model regresi yang baik adalah memiliki distribusi normal atau mendekati normal. Untuk mengujinya digunakan uji Kolmogorov - Sminorv. Kriteria pengujian yaitu apabila nilai Asymp.Sig ( 2 tailed $)>\alpha(0,05)$ maka data telah terdistribusi normal.

a. Pengaruh PDRB dan Aset terhadap Penerimaan Daerah

Hasil perhitungan uji normalitas dapat dilihat pada tabel 3.1

Tabel 3.1. Hasil Uji Normalitas One - sample Kolmogorov Sminorv.

\begin{tabular}{lc}
\hline Keterangan & $\begin{array}{c}\text { Standardized } \\
\text { Residual }\end{array}$ \\
\hline $\mathrm{N}$ & 35 \\
Kolmogorov-Smirnov Z & 0,732 \\
Asymp. Sig. (2-tailed) & 0,657 \\
\hline
\end{tabular}

Sumber: Hasil Data Diolah Sendiri

Berdasarkan tabel 3.1 diatas terlihat bahwa nilai Asymp. Sig. (2-tailed )sebesar 0,657> nilai alpha sebesar 0,05. Hal ini berarti nilai residual terstandarisasi dinyatakan menyebar secara normal.

b. Pengaruh Penerimaan Daerah terhadap Kinerja Keuangan Hasil perhitungan uji normalitas dapat dilihat pada tabel 3.2

Tabel 3.2. Hasil Uji Normalitas One - sample Kolmogorov Sminorv.

\begin{tabular}{lc}
\hline Keterangan & $\begin{array}{c}\text { Standardized } \\
\text { Residual }\end{array}$ \\
\hline N & 35 \\
Kolmogorov-Smirnov Z & 0,976 \\
Asymp. Sig. (2-tailed) & 0,296 \\
\hline
\end{tabular}

Sumber: Hasil Data Diolah Sendiri

Berdasarkan tabel 3.2 diatas terlihat bahwa nilai Asymp. Sig. (2-tailed) sebesar 0,296> nilai alpha sebesar 0,05. Hal ini berarti nilai residual terstandarisasi dinyatakan menyebar secara normal. 


\section{Uji Multikolinearitas}

Uji multikolinearitas bertujuan untuk mengetahui ada tidaknya gejala multikolinearitas dapat dilihat dari nilai VIF ( Variance Inflation Factor ). Kriteria pengujianVIF>10 ada gejala multikolinearitas, VIF $\leq 10$ tidak ada gejala multikolinearitas.

a. Pengaruh PDRB dan Aset terhadap Penerimaan Daerah

Perhitungan VIF dapat dilihat pada tabel berikut :

Tabel 3.3 Uji Multikoliniearitas

\begin{tabular}{lc}
\multicolumn{1}{c}{ Variabel } & VIF \\
\hline PDRB & 1,085 \\
Aset & 1,085 \\
\hline
\end{tabular}

Sumber: Hasil Data Diolah Sendiri

Berdasarkan tabel 3.3 dapat diketahui bahwa masing - masing nilai VIF kurang dari 10. Maka dapat dilihat bahwa dalam persamaan regresi tidak terdapat gejala multikolinearitas

b. Pengaruh Penerimaan Daerah terhadap Kinerja Keuangan

Uji Multikolinieritas tidak dilakukan karena merupakan regresi linier sederhana dan hanya memiliki satu variabel bebas.

\section{Uji Heteroskedastisitas}

Heteroskedastisitas akan mengakibatkan penaksiran koefisien - koefisien regresi menjadi tidak efisien. Hasil penaksiran akan menjadi kurang dari semestinya. Heteroskedastisitas bertentangan dengan regresi linier, yaitu bahwa variasi residual sama untuk semua pengamatan atau disebut homoskedastisitas Gujarati (1995). Pengujian ada tidaknya heteroskedastisitas menggunakan uji gleyser. Jika nilai signifikansinya ( $\alpha$ ) lebih dari 0,05 maka dapat dipastikan tidak ada gejala heteroskedastisitas.

a. Pengaruh PDRB dan Aset Terhadap Penerimaan Daerah

Tabel 3.4.Uji Heteroskedastisitas

\begin{tabular}{lc}
\multicolumn{1}{c}{ Variabel } & Sig \\
\hline PDRB & 0,532 \\
Aset & 0,906 \\
\hline
\end{tabular}

Sumber: Hasil Data Diolah Sendiri

Berdasarkan hasil perhitungan heteroskedastisitas yang ditunjukkan oleh tabel 3.4 terlihat nilai signifikansi variabel PDRB sebesar 0,532 dan nilai signifikansi variabel aset sebesar 0,906. Hasil pengujian tersebut menunjukkan bahwa seluruh variabel memiliki nilai sginifikansi lebih besar dari 0,05 sehingga lolos uji asumsi heteroskedastisitas.

b. Pengaruh Penerimaan Daerah terhadap Kinerja Keuangan

Tabel 3.5 Uji Heteroskedastisitas

\begin{tabular}{l} 
Variabel \\
\multicolumn{1}{c}{ Sig } \\
Penerimaan Daerah 0,714 \\
Sumber: Hasil Data Diolah Sendiri \\
Berdasarkan hasil perhitungan heteroskedastisitas yang ditunjukkan \\
oleh tabel 3.5 terlihat nilai signifikansi variabel penerimaan daerah \\
sebesar $0,714$. Hasil pengujian tersebut menunjukkan bahwa variabel
\end{tabular}


4. Uji Autokorelasi

penerimaan daerah memiliki nilai sginifikansi lebih besar dari 0,05 sehingga lolos uji asumsi heteroskedastisitas.

Uji autokorelasi digunakan untuk mengetahui apakah terjadi korelasi antar residu serangkaian data observasi yang diuraikan menurut waktu (time series) atau ruang (cross sectional). Hal ini berarti bahwa suatu tahun tertentu dipengaruhi oleh tahun berikutnya. Untuk menguji ada tidaknya autokorelasi dilakukan dengan menggunakan Lagrange Multiplier ( LM Test ) yaitu dengan membandingkan $X^{2}$ hitung dengan $X^{2}$ tabel dengan $d f=(\alpha, n-$ 1). Jika nilai $X^{2}$ hitung $>X^{2}$ tabel, hal itu menunjukkan adanya masalah autokorelasi. Sebaliknya, jika $X^{2} h i t u n g \leq X^{2}$ tabel, hal itu menunjukkan tidak terjadi masalah autokorelasi.

a. Pengaruh PDRB dan Aset Terhadap Penerimaan Daerah

\section{Tabel 3.6 Uji Autokorelasi}

\begin{tabular}{cc}
\hline Model & R Square \\
\hline 1 & 0,033
\end{tabular}

Sumber: Hasil Data Diolah Sendiri

Berdasarkan output di atas diperoleh nilai $R$ Square sebesar 0,033 dan jumlah $n$ 35, maka $X^{2}$ hitung sebesar $(34 \times 0,033)=1,122$, sedangkan $\mathrm{X}^{2}$ tabel sebesar 48,602 karena $\mathrm{X}^{2}$ hitung $\leq \mathrm{X}^{2}$ tabel, maka model persamaan regresi tidak mengandung masalah autokorelasi

b. Pengaruh Penerimaan Daerah Terhadap Kinerja Keuangan

\section{Tabel 3.7 Uji Autokorelasi}

\begin{tabular}{cc}
\hline Model & R Square \\
\hline 1 & 0,238 \\
\hline
\end{tabular}

\section{Sumber: Hasil Data Diolah Sendiri}

Berdasarkan output di atas diperoleh nilai $R$ Square sebesar 0,238 dan jumlah $n$ 35, maka $X^{2}$ hitung sebesar $(34 \times 0,238)=8,092$, sedangkan $X^{2}$ tabel sebesar 48,602 karena $X^{2}$ hitung $\leq X^{2}$ tabel, maka model persamaan regresi tidak mengandung masalah autokorelasi

\section{Analisis Regresi}

Untuk mengetahui pengaruh PDRB dan aset terhadap Penerimaan Daerah digunakan metode regresi linier berganda dengan bantuan SPSS 17.0 for windows

Tabel 3.8 Koefisien Persamaan Garis Regresi

\begin{tabular}{lccc}
\hline Variabel & $\begin{array}{c}\text { Unstandardized } \\
\text { Coefficients }\end{array}$ & $\mathrm{t}$ & Sig. \\
\hline (Constant) & 6,774 & 8,101 & 0,000 \\
PDRB & 0,346 & 7,337 & 0,000 \\
Aset & 0,057 & 0,911 & 0,369 \\
\hline
\end{tabular}

Sumber: Hasil Data Diolah Sendiri

Berdasarkan tabel 3.8 dengan menggunakan koefisien regresi diperoleh persamaan regresi sebagai berikut :

$$
M=6,774+0,346 X_{1}+0,057 X_{2}+\varepsilon
$$

Berdasarkan hasil perhitungan di atas, maka hasil koefisien regresinya sebagai berikut :

1) $\mathrm{a}=6,774$ 
Nilai konstanta ini menunjukkan bahwa apabila variabel PDRB dan aset bernilai 0 maka penerimaan daerah sebesar 6,774.

2) $b_{1}=0,346$

Nilai koefisien b1 menunjukkan bahwa variabel PDRB berpengaruh positif terhadap penerimaan daerah. Apabila variabel independen lainnya tetap $\left(X_{2}=0\right)$, maka setiap kenaikan per satuan PDRB akan menaikkan penerimaan daerah sebesar 0,346

3) $b_{2}=0,057$

Nilai koefisien $b_{2}$ menunjukkan bahwa variabel aset berpengaruh positif terhadap penerimaan daerah. Apabila variabel independen lainnya tetap $\left(X_{1}=0\right)$, maka setiap kenaikan per satuan aset akan menaikkan penerimaan daerah sebesar 0,057

4) Koefisien Determinasi ( $R$ Square )

Tabel 3.9. Koefisien Determinasi

\begin{tabular}{cccc}
\hline $\mathrm{R}$ & $\mathrm{R}$ Square & Adjusted R Square & $\begin{array}{c}\text { Std. Error of the } \\
\text { Estimate }\end{array}$ \\
\hline $0,815^{\mathrm{a}}$ & 0,664 & 0,643 & 0,07780 \\
\hline
\end{tabular}

Sumber: Hasil Data Diolah Sendiri

Berdasarkan tabel 3.9 hasil perhitungan regresi berganda, diperoleh hasil Adjusted $R$ Square sebesar 0,643. Hal ini menunjukkan bahwa 64,30\% variabel dependen (penerimaan daerah) dijelaskan dan dipengaruhi oleh variabel independen (PDRB dan Aset). Hal ini berarti masih terdapat 35,70\% faktor lain yang mempengaruhi penerimaan daerah

\section{Pengujian Hipotesis}

Untuk mengetahui pengaruh PDRB dan aset terhadap penerimaan daerah digunakan uji t satu ujung. Berdasarkan tabel 3.8 dapat diketahui bahwa pengaruh setiap variabel independen terhadap variabel dependen sebagai berikut :

1) Hipotesis pertama

Berdasar hasil perhitungan statistik regresi linier berganda diperoleh nilai t hitung variabel PDRB sebesar 7,337 dengan nilai signifikansi 0,000 sedangkan nilai $t$ tabel sebesar 1,694 . Hal ini berarti $t$ hitung lebih besar dari $t$ tabel dan nilai signifikansi $<\alpha(0,05)$. Hal ini menunjukkan bahwa variabel PDRB berpengaruh positif signifikan terhadap penerimaan daerah. Dengan demikian hipotesis yang menyatakan PDRB berpengaruh positif signifikan terhadap penerimaan daerah, diterima.

2) Hipotesis kedua

Berdasar hasil perhitungan statistik regresi linier berganda diperoleh nilai $t$ hitung variabel aset sebesar 0,911 dengan nilai signifikansi 0,369 sedangkan nilai $t$ tabel sebesar 1,694. Hal ini berarti $t$ hitung lebih kecil dari $t$ tabel dan nilai signifikansi $>\alpha(0,05)$. Hal ini menunjukkan bahwa variabel aset tidak berpengaruh positif signifikan terhadap penerimaan daerah. Dengan demikian hipotesis yang menyatakan aset berpengaruh positif signifikan terhadap penerimaan daerah, ditolak.

3) Hipotesis ketiga

a) Analisis Regresi

Untuk menganalisa pengaruh antar variabel Penerimaan Daerah terhadap kinerja keuangan digunakan metode analisis regresi linier sederhana dengan bantuan SPSS 17.0 for Windows

Tabel 3.10 Koefisien Persamaan Regresi 


\begin{tabular}{ccccccc}
\hline \multirow{2}{*}{ Model } & \multicolumn{2}{c}{$\begin{array}{l}\text { Unstandardized } \\
\text { Coefficients }\end{array}$} & \multicolumn{2}{c}{$\begin{array}{c}\text { Standardized } \\
\text { Coefficients }\end{array}$} & & \\
\cline { 2 - 4 } & $\mathrm{B}$ & Std. Error & Beta & $\mathrm{t}$ & Sig. \\
\hline $1 \quad$ (Constant) & 14,210 & 5,327 & & 2,668 & 0,012 \\
Penerimaan Daerah & $-0,966$ & 0,447 & $-0,352$ & $-2,162$ & 0,038 \\
\hline Sumber: Hasil Data Diolah Sendiri & & & &
\end{tabular}

Berdasarkan tabel 3.10, dengan menggunakan koefisien regresi diperoleh persamaan regresi sebagai berikut :

$Y=14,210-0,966 M+\varepsilon$

Berdasarkan hasil perhitungan diatas maka hasil koefisien regresinya dapat diinterpretasikan sebagai berikut :

1) $\mathrm{a}=14,210$

Nilai konstanta menunjukkan bahwa apabila variabel penerimaan daerah bernilai 0 maka kinerja keuangan sebesar 14,210

2) $b_{3}=-0,966$

Nilai koefisien $b_{3}$ menunjukkan bahwa variabel penerimaan daerah berpengaruh negatif terhadap kinerja keuangan, maka setiap kenaikan per satuan penerimaan daerah akan menurunkan kinerja keuangansebesar 0,966

b) Koefisien Determinasi ( $R$ Square)

Tabel 3.11 Koefisien Determinasi

\begin{tabular}{cccc}
\hline $\mathrm{R}$ & $\mathrm{R}$ Square & Adjusted R Square & $\begin{array}{c}\text { Std. Error of the } \\
\text { Estimate }\end{array}$ \\
\hline 0,352 & 0,124 & 0,098 & 0,33949 \\
$\mathrm{a}$ & & & \\
\hline
\end{tabular}

Sumber: Hasil Data Diolah Sendiri

Berdasarkan tabel 3.11 hasil perhitungan regresi sederhana, diperoleh hasil Adjusted R Square sebesar 0,098. Berdasarkan tabel 3.11 hasil perhitungan regresi berganda, diperoleh hasil Adjusted $R$ Square sebesar 0,098 . Hal ini menunjukkan bahwa $9,80 \%$ variabel dependen (kinerja keuangan) dijelaskan dan dipengaruhi oleh variabel independen (Penerimaan Daerah). Hal ini berarti masih terdapat 90,20\% faktor lain yang mempengaruhi kinerja keuangan.

Untuk mengetahui pengaruh variabel Penerimaan Daerah terhadap variabel Kinerja Keuangan digunakan uji $t$ satu ujung. Berdasar hasil perhitungan statistik regresi linier pada tabel 3.10 variabel penerimaan daerah diperoleh nilai $t$ hitung sebesar $-2,162$ dengan nilai signifikansi 0,038 sedangkan nilai t tabel sebesar 1,692. Ini berarti nilai t hitung lebih kecil dari t tabel dan nilai signifikansi $<\alpha(0,05)$. Hal ini menunjukkan bahwa variabel Penerimaan Daerah berpengaruh negatif signifikan terhadap kinerja keuangan. Dengan demikian hipotesis yang menyatakan Penerimaan Daerah berpengaruh positif dan signifikan terhadap kinerja keuangan ditolak.

4) Hipotesis keempat

Analisis regresi variabel mediasi dalam penelitian ini menggunakan kausal step dikembangkan oleh Baron dan Kenny (1986). Analisis regresi 
mediasi dengan metode kausal step dilakukan dengan langkah sebagai berikut :

a). Membuat persamaan regresi variabel bebas $(X)$ terhadap variabel tergantung $(\mathrm{Y})$

Tabel 3.12 Koefisien Persamaan Regresi

\begin{tabular}{lcc}
\hline Variabel & $\begin{array}{c}\text { Unstandardized } \\
\text { Coefficients }\end{array}$ & Sig. \\
\hline (Constant) & 2,378 & 0,551 \\
PDRB & $-0,078$ & 0,728 \\
Aset & 0,107 & 0,719 \\
\hline
\end{tabular}

Sumber: Hasil Data Diolah Sendiri

b). Membuat persamaan regresi variabel bebas $(X)$ terhadap variabel mediasi (M)

Tabel 3.13. Koefisien Persamaan Regresi

\begin{tabular}{lcc}
\hline Variabel & $\begin{array}{c}\text { Unstandardized } \\
\text { Coefficients }\end{array}$ & Sig. \\
\hline (Constant) & 6,774 & 0,000 \\
PDRB & 0,346 & 0,000 \\
Aset & 0,057 & 0,369 \\
\hline
\end{tabular}

Sumber: Hasil Data Diolah Sendiri

c). Membuat persamaan regresi variabel bebas $(X)$ terhadap variabel tergantung $(\mathrm{Y})$ dengan memasukkan variabel mediasi $(\mathrm{M})$ dalam persamaan

Tabel 3.14 Koefisien Persamaan Regresi

\begin{tabular}{lcc}
\hline Variabel & $\begin{array}{c}\text { Unstandardized } \\
\text { Coefficients }\end{array}$ & Sig. \\
\hline (Constant) & 20,154 & 0,002 \\
PDRB & 0,829 & 0,011
\end{tabular}

Aset

$\begin{array}{lll} & -0,256 & 0,317 \\ \text { Penerimaan } & -2,624 & 0,001\end{array}$

Daerah

Sumber: Hasil Data Diolah Sendiri

Unstandardized Coefficient pada persamaan pertama PDRB terhadap kinerja keuangan sebesar $-0,078$ dengan signifikansi 0,728 berarti tidak terdapat pengaruh positif signifikan antara PDRB dengan kinerja keuangan. Unstandardized Coefficient pada persamaan kedua PDRB terhadap penerimaan daerah sebesar 0,346 dan dengan signifikansi 0,000 berarti terdapat pengaruh positif signifikan antara PDRB dengan penerimaan daerah. Unstandardized Coefficient pada persamaan ketiga PDRB terhadap kinerja keuangan dengan memasukkan variabel penerimaan daerah sebesar 0,829 dengan 
signifikansi 0,011. Unstandardized Coefficient penerimaan daerah terhadap kinerja keuangan sebesar -2,624 dengan signifikansi 0,001 sehingga terdapat pengaruh negatif signifikan penerimaan daerah terhadap kinerja keuangan

Berdasarkan hasil analisis diatas diketahui bahwa variabel bebas (PDRB) berpengaruh terhadap variabel mediasi (penerimaan daerah). Variabel mediasi berpengaruh negatif terhadap variabel tergantung (kinerja keuangan). Setelah memasukkan variabel mediasi, variabel bebas tetap tidak berpengaruh terhadap variabel tergantung, sehingga dapat disimpulkan bahwa penerimaan daerah tidak memediasi hubungan antara PDRB dengan kinerja keuangan.

Unstandardized Coefficient pada persamaan pertama Aset terhadap kinerja keuangan sebesar 0,107 dengan signifikansi 0,719 berarti tidak terdapat pengaruh antara aset dan kinerja keuangan. Unstandardized Coefficient pada persamaan kedua Aset terhadap penerimaan daerah sebesar 0,057 dengan signifikansi 0,369 berarti tidak terdapat pengaruh antara aset dan penerimaan daerah. Unstandardized Coefficient pada persamaan ketiga Aset terhadap kinerja keuangan dengan memasukkan variabel penerimaan daerah sebesar 0,256 dengan signifikansi 0,317 sehingga tidak terdapat pengaruh aset terhadap kinerja keuangan. Unstandardized Coefficient penerimaan daerah terhadap kinerja keuangan sebesar -2,624 dengan signifikansi 0,001 sehingga terdapat pengaruh penerimaan daerah terhadap kinerja keuangan

Berdasarkan hasil analisis diatas diketahui bahwa variabel bebas (Aset ) tidak berpengaruh terhadap variabel mediasi (penerimaan daerah). Variabel mediasi tidak berpengaruh terhadap variabel kinerja keuangan setelah memasukkan variabel mediasi, variabel bebas tetap tidak berpengaruh terhadap variabel tergantung, sehingga dapat disimpulkan bahwa penerimaan daerah tidak memediasi hubungan antara Aset dengan kinerja keuangan. Dengan demikian hipotesis yang menyatakan penerimaan daerah memediasi PDRB dan Aset dengan kinerja keuangan

\section{ditolak.}

\section{PEMBAHASAN}

\section{Produk Domestik Regional Bruto dengan Penerimaan Daerah}

Hasil penelitian ini menunjukkan bahwa PDRB berpengaruh positif terhadap penerimaan daerah. Hasil penelitian ini mendukung penelitian yang dilakukan oleh Muhamad (2005) yang menyatakan bahwa PDRB berpengaruh terhadap PAD. Penelitian ini juga sejalan dengan penelitian Rahmadi (2011) dengan hasil PDRB memiliki pengaruh positif dan signifikan terhadap PAD, pajak, retribusi, BUMD, penerimaan lain yang sah, Bagi Hasil Pajak dan Bukan Pajak, penerimaan daerah lainnya, dana perimbangan, DAU. Penelitian ini juga mendukung penelitian Datu (2012) yang menyatakan bahwaPDRB berpengaruh positif dan signifikan terhadap PAD.

PDRB adalah nilai barang dan jasa yang dihasilkan oleh suatu daerah dalam jangka waktu tertentu. Semakin meningkatnya PDRB yang dihasilkan oleh suatu daerah akan semakin meningkatkan produksinya. Hasil produksi masyarakat tersebut dapat digunakan oleh pemerintah untuk meningkatkan pelayanan kepada masyarakat dan pengadaan barang dan jasa publik. Pemerintah dapat mengambil hasil produksi tersebut dalam bentuk pajak, 
semakin meningkatnya nilai barang dan jasa yang diproduksi oleh suatu daerah maka akan semakin meningkatkan pajak yang diterima oleh pemerintah. Dengan meningkatnya penerimaan di sektor pajak maka Pendapatan Asli Daerah juga akan meningkat. Dengan PAD yang baik akan mengurangi ketergantungan pemerintah daerah kepada pemerintah pusat sehingga pemerintah daerah akan lebih baik dalam mengelola sumber daya yang dimilikinya.

PDRB juga digunakan untuk mengetahui perkembangan dan struktur ekonomi suatu wilayah, sehingga pemerintah daerah dan menentukan arah pembangunannya. Pemerintah daerah juga dapat mengembangkan potensi daerahnya melalui investasi pemerintah pada barang publik yang dapat mendorong setiap sektor yang memberikan kontribusi pada PDRB untuk meningkatkan PDRB. Semakin besar PDRB yang diperoleh maka akan semakin besar pula potensi penerimaan daerah. Jadi dengan adanya peningkatan PDRB maka hal ini mengindikasikan akan mendorong peningkatan pendapatan asli daerah Saragih (2003).

Berdasarkan output korelasi PDRB dengan Dana Perimbangan, DAU, DAK dan DBH diperoleh kesimpulan bahwa koefisien korelasi PDRB dengan dana perimbangan $74,5 \%$, hal ini menunjukkan bahwa korelasi antara PDRB dengan dana perimbangan bernilai positif berarti hubungan searah. Koefisien korelasi PDRB dengan DAU sebesar $71,2 \%$, hal ini menunjukkan bahwa korelasi antara PDRB dengan DAU bernilai positif berarti hubungan searah.Koefisien korelasi PDRB dengan DAK sebesar 30,1\%, hal ini menunjukkan bahwa korelasi antara PDRB dengan DAK bernilai positif berarti hubungan searah. Koefisien korelasi PDRB dengan DBH sebesar $86,0 \%$, hal ini menunjukkan bahwa korelasi antara PDRB dengan DBH bernilai positif berarti hubungan searah. PDRB memiliki korelasi sangat kuat dengan Dana Bagi Hasil.Dana Bagi Hasil (DBH) adalah dana yang bersumber dari pendapatan APBN yang dialokasikan kepada Daerah berdasarkan angka persentase tertentu untuk mendanai kebutuhan Daerah dalam rangka pelaksanaan Desentralisasi. Pengaturan DBH dalam UndangUndang Nomor 33 Tahun 2004 tentang Perimbangan Keuangan Antara Pusat dan Pemerintahan Daerah.DBH merupakan pendapatan yang berasal dari daerah yang menjadi kewenangan pemerintah pusat, kemudian dibagikan kepada daerah secara proposional. Hal ini berarti PDRB yang menggambarkan pertumbuhan ekonomi suatu daerah, memiliki hubungan erat dengan dana bagi hasil. 
Tabel 4.1 Dana Bagi Hasil

\begin{tabular}{ccccccc}
\hline & & \multirow{2}{*}{ No untuk } & \multicolumn{4}{c}{ Proporsi } \\
\cline { 3 - 6 } & Jenis & Daerah & Prov & $\begin{array}{c}\text { Kab/ Kota } \\
\text { Penghasil }\end{array}$ & $\begin{array}{c}\text { Kab/ Kota } \\
\text { Lain DIm Prov }\end{array}$ & $\begin{array}{c}\text { Upah } \\
\text { Pungut }\end{array}$ \\
\hline 1 & PBB & $90 \%$ & $16,20 \%$ & $64,80 \%$ & $9 \%$ \\
2 & BPHTB & $80 \%$ & $16 \%$ & $64 \%$ & \\
3 & PPH & $20 \%$ & $8 \%$ & & $\left.12 \%{ }^{*}\right)$ \\
4 & CUKAI & $2 \%$ & $0,60 \%$ & $0,80 \%$ & $0,60 \%$ \\
\hline \multicolumn{4}{c}{ *) $8,4 \%$ Kab/Kota tempat WP dan 3,6\% Kab/Kota dalam Prov yg sama } \\
\multicolumn{4}{c}{ Sumber : Buku Pegangan 2009, Pelaksanaan Desentralisasi Fiskal. DepKeu }
\end{tabular}

\section{Aset Pemerintah Daerah dengan Penerimaan Daerah}

Hasil penelitian ini menunjukkan bahwa aset tidak berpengaruh terhadap penerimaan daerah, Hasil penelitian ini sejalan dengan penelitian Putri (2013) yang menyatakan bahwa aset yang dimiliki pemerintah daerah sebagian besar masih rendah dan terjadi karena pemerintah daerah belum sepenuhnya mampu menggali sumber daya yang dimiliki dalam mendukung penyelenggaraan pemerintahannya. Hasil penelitian ini tidak sejalan dengan penelitian Sutaryo (2013) yang menyatakan bahwa aset daerah berpengaruh terhadap penerimaan daerah.

Hasil penelitian ini mendukung penelitian Putri (2013) karena berdasar informasi yang diperoleh dari BPK, adanya temuan tentang penyajian aset yang tidak akurat dalam neraca menyebabkan besarnya aset belum dapat mencerminkan potensi yang ada aset merupakan sumber daya yang penting untuk meningkatkan Pendapatan Asli Daerah sehingga diperlukan pengelolaan baik meliputi perencanaan kebutuhan dan penganggaran, pengadaan, penerimaan, penyimpanan dan penyaluran, penggunaan, penatausahaan, pemanfaataan atau penggunaan, pengamanan dan pemeliharaan, penilaian, penghapusan, pemindahtanganan, pembinaan, pengawasan dan pengendalian, pembiayaan dan tuntutan ganti rugi sehingga mampu memberikan kontribusi optimal terhadap pemerintah daerah.

Besarnya aset yang dimiliki oleh pemerintah kabupaten/kota di Jawa Tengah diduga belum dimanfaatkan dengan efektif dan efisien sehingga belum dapat memberikan penerimaan daerah yang besar. Pemerintah daerah perlu meningkatkan pengelolaan asetnya sehingga dapat meningkatkan penerimaan daerah.

\section{Penerimaan Daerah dengan Kinerja Keuangan}

Hasil penelitian ini menunjukkan bahwa penerimaan daerah berpengaruh negatif signifikan terhadap kinerja keuangan. Hasil penelitian ini sejalan dengan penelitian Simbolon (2011) yang menyatakan bahwa Dana Bagi Hasil (DBH), Dana Alokasi Umum (DAU), dan Dana Alokasi Khusus (DAK) berpengaruh secara signifikan negatif terhadap Tingkat Kemandirian Keuangan Daerah. Penelitian yang dilakukan Rahim (2008) yang menunjukkan hasil bahwa Dana Perimbangan yang diterima oleh pemerintah daerah dari pemerintah pusat tidak berpengaruh signifikan terhadap peningkatan kinerja keuangan pemerintah daerah. Dana Perimbangan yang diterima melalui DAU dan DAK tidak memberikan dampak positif terhadap 
kinerja keuangan Pemerintah Daerah Kabupaten Takalar. Penerimaan yang didominasi oleh dana perimbangan akan menyebabkan ketergantungan pemerintah daerah terhadap pemerintah pusat tinggi sehingga akan menurunkan kinerja keuangannya. Florida (2006) menyatakan bahwa pembagian laba BUMD dan penerimaan lain-lain yang sah bukan pajak tidak berpengaruh terhadap kinerja keuangan. Putri (2013) menyimpulkan bahwa DAK tidak berpengaruh terhadap kinerja keuangan.

Hasil penelitian ini tidak sejalan dengan penelitian Florida (2006) yang menyatakan bahwa terdapat pengaruh PAD secara simultan terhadap kinerja keuangan. Penelitian ini tidak sejalan dengan penelitian Julitawati (2012) yang menyatakan bahwa PAD dan Dana Perimbangan secara simultan dan parsial berpengaruhterhadap kinerja keuangan pemerintah kabupaten/kota di Provinsi Aceh.Penelitian ini juga tidak sejalan dengan Putri ( 2013 ) menyimpulkan bahwa DBH, DAU berpengaruh terhadap kinerja keuangan.

Hasil penelitian ini mendukung penelitian Rahim (2008) yang menyatakan bahwa dana perimbangan yang diterima oleh pemerintah daerah dari pemerintah pusat tidak berpengaruh signifikan terhadap peningkatan kinerja keuangan pemerintah daerah. Penerimaan daerah pemerintah kabupaten/kota di Jawa Tengah berdasar data statistik keuangan pemerintah provinsi tahun 2007 sampai dengan tahun 2010 diperoleh hasil bahwa penerimaan kabupaten/kota di Jawa Tengah lebih dari 50\% berasal dari dana perimbangan. Hal ini berarti pemerintah daerah dituntut untuk lebih meningkatkan penerimaan daerah terutama yang berasal dari Pendapatan Asli Daerah sehingga dengan meningkatnya penerimaan daerah akan dapat meningkatkan kinerja keuangan pemerintah daerah.

Kinerja Keuangan dalam penelitian ini menggunakan kapasitas fiskal, rasio desentralisasi fiskal, rasio kemandirian, rasio efektivitas dan rasio efisien. Berdasar hasil penghitungan rasio kemandirian menggunakan rumus yang diambil dari Bisma (2010) yaitu PAD/ Dana Perimbangan x 100\% diperoleh hasil bahwa Kota Semarang memiliki rasio kemandirian tertinggi yaitu $37,14 \%$ dan terendah dimiliki oleh Kabupaten Klaten sebesar 6,62\%, rata-rata desentralisasi fiskal diperoleh hasil bahwa Kota Semarang memiliki rasio desentralisasi fiskal tertinggi yaitu $21,74 \%$ dan terendah dimiliki oleh Kabupaten Klaten sebesar 5,17. Rasio efektivitas nilai terendah 92,01\% dimiliki oleh Kabupaten Klaten dan tertinggi 153,28\% dimiliki oleh Kabupaten Banyumas, rata-rata efektivitas pemerintah kabupaten/kota di Jawa Tengah sebesar sebesar $116,43 \%$ berarti sangat efektif dalam mecapai PAD yang telah ditargetkan Rasio efisiensi nilai terendah 96,32\% dimiliki oleh Kabupaten Banyumas dan tertinggi 126,05\% dimiliki oleh Kota Tegal, ratarata efisiensi pemerintah kabupaten/kota di Jawa Tengah sebesar 109,11\% hal ini berarti pemerintah daerah tidak efisien dalam penggunaan penerimaan daerah untuk kebutuhan belanjanya dalam memberikan pelayanan kepada masyarakat. Sedangkan kapasitas fiskal terendah dimiliki oleh Kabupaten Pemalang sebesar 0,06 dan tertinggi dimiliki oleh 0,82.

Hal ini berarti Pemerintah Daerah perlu meningkatkan penerimaan daerah yang berasal dari pendapatan asli daerah. Sehingga PAD dapat memberikan kontribusi terbesar dalam penerimaan daerah dengan demikian penerimaan daerah yang tinggi yang berasal dari PAD dapat meningkatkan kinerja keuangan pemerintah daerah. 


\section{Penerimaan Daerah memediasi PDRB dan aset dengan Kinerja Keuangan}

Hasil penelitian ini adalah penerimaan daerah tidak memediasi hubungan PDRB dan Aset terhadap kinerja keuangan.Berdasarkan hasil analisis diatas diketahui bahwa variabel bebas (PDRB) berpengaruh terhadap variabel mediasi (penerimaan daerah). Variabel mediasi berpengaruh negatif terhadap variabel tergantung (kinerja keuangan). Setelah memasukkan variabel mediasi, variabel bebas tetap tidak berpengaruh terhadap variabel tergantung, sehingga dapat disimpulkan bahwa penerimaan daerah tidak memediasi hubungan antara PDRB dengan kinerja keuangan.

Berdasarkan hasil analisis diatas diketahui bahwa variabel bebas (aset) tidak berpengaruh terhadap variabel mediasi (penerimaan daerah). Variabel mediasi tidak berpengaruh terhadap variabel kinerja keuangan Setelah memasukkan variabel mediasi, variabel bebas tetap tidak berpengaruh terhadap variabel tergantung, sehingga dapat disimpulkan bahwa penerimaan daerah tidak memediasi hubungan antara Aset dengan kinerja keuangan

Hal ini berarti PDRB dan Aset dapat berpengaruh langsung terhadap kinerja keuangan tanpa melalui penerimaan daerah.Peningkatan PDRB dapat langsung meningkatkan kinerja keuangan dan peningkatan aset dapat langsung meningkatkan kinerja keuangan.

\section{KESIMPULAN}

Berdasarkan hasil analisis dan pembahasan yang telah dilakukan, maka dapat ditarik beberapa kesimpulan sebagai berikut :

1. Berdasarkan analisis regresi PDRB dan Aset terhadap penerimaan daerah diperoleh hasil bahwa PDRB berpengaruh positif signifikan terhadap penerimaan daerah.

2. Berdasarkan analisis regresi PDRB dan Aset terhadap penerimaan daerah diperoleh hasil bahwa aset tidak berpengaruh terhadap penerimaan daerah.

3. Berdasarkan analisis regresi Penerimaan Daerah dengan Kinerja Keuangan diperoleh hasil bahwa Penerimaan Daerah berpengaruh negatif signifikan terhadap kinerja keuangan. Kinerja keuangan pemerintah daerah dalam penelitian ini menggunakan rasio kapasitas fiskal, rasio desentralisasi fiskal, kemandirian, rasio efektivitas dan rasio efisiensi.

4. Berdasarkan analisis regresi mediasi dengan metode kausal step diperoleh hasil bahwa Penerimaan Daerah tidak memediasi hubungan PDRB dan Aset dengan kinerja keuangan. 


\section{DAFTAR PUSTAKA}

Abdullah, Syukriy. 2006. Perilaku Oportunistik dalam Penganggaran Daerah: Bukti Empiris atas Aplikasi Agency Theory di Sektor Publik. Makalah Dipresentasikan dalam Simposium Nasional Akuntansi IX, Padang 23-26 Agustus 2006

Agustina, Oesi. 2013. Jurnal Analisis Kinerja Pengelolaan Keuangan Daerah dan Tingkat Kemandirian Daerah Di Era Otonomi Daerah: Studi Kasus Kota Malang (Tahun Anggaran 2007-2011). Universitas Brawijaya.

Bappenas. 2003." PAD terhadap PDRB". Jakarta : Erlangga

Bastian, Indra. 2006. Sistem Akuntansi Sektor Publik.Jakarta : Bagian Penerbitan Salemba Empat

Bawono, Halim, Lord. 2012. Public Sector Performance Measurement and Budget Allocation : An Indonesian Experiment. Presented at 6th NZ Management AccountingConference, Palmerston North, 22-23 Nov 2012

Bisma, I Dewa Gde dan Hery Susanto. Evaluasi Kinerja Keuangan Daerah Pemerintah Provinsi Nusa Tenggara Barat Tahun Anggaran 2003 2007. GaneÇ Swara Edisi Khusus Vol. 4 No.3, Desember 2010

Budiarto, Bambang. 2007. Pengukuran Keberhasilan Pengelolaan Keuangan Daerah.Seminar Ekonomi Daerah. Surabaya.

Darmastuti, Dewi, Setyaningrum Dyah. 2012. Faktor-faktor yang Mempengaruhi Pengungkapan Belanja Bantuan Sosial Pada Laporan Keuangan Pemerintah Daerah Pada Tahun 2009. Simposium Nasional Akuntansi IV.Banjarmasin

Datu, Indra Rindu. 2012. Analisis Faktor Yang Mempengaruhi Pendapatan Asli Daerah (PAD) di Makassar Tahun 1999 - 2009. Universitas Hasanudin

FASB, Statement of Financial Acounting Concept No. 6, Prg 25/1985,

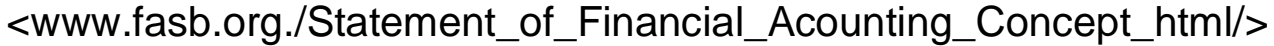

Febriyanto, Iwan Ismi. 2012. Dialektika kebijakan publik : Studi Komparasi Teori New Public Management Dengan Good Governance Dalam Perspektif Kebijakan Publik. dalam http://sosialitadanpolitik.blogspot.co.id diakses 10 Februari 2016

Florida, Asha. 2006. Pengaruh PAD Terhadap Kinerja Keuangan Pemerintah Kabupaten Dan Kota Di Propinsi Sumatera Utara. Tesis. Universitas Sumatera Utara

Ghozali., Imam. 2009. Ekomometrika: Teori, Konsep, dan, Aplikasi dengan SPSS 17. Badan Penerbit Universitas Diponogoro. Semarang

Gujarati., Sumarno Zain. 1995. Ekonometrika Dasar. Erlangga. Jakarta

Hakim simanjutak.blogspot.com diakses 10 Juni 2013 pukul 21.06

Halim, Abdul. 2001. Bunga Rampai :Manajemen Keuangan Daerah. UPP AMP YKPN. Yogyakarta .

Halim, Abdul.2001. Anggaran Daerah dan "fiscal stress" ( sebuah studi kasus pada Anggaran daerah provinsi di Indonesia). Jurnal Ekonomi dan Bisnis Indonesia.

Halim, Abdul., 200. Akuntansi Sektor Publik-Akuntansi Keuangan Daerah. Salemba Empat. Jakarta.

Halim, Abdul. 2002. Akuntansi Keuangan Daerah. Salemba Empat. Jakarta

Halim, Abdul. 2007. Akuntansi Sektor Publik: Akuntansi Keuangan Daerah. Salemba Empat. Jakarta 
Halim, Abdul dan Abdullah, Syukriy.2006. Hubungan dan Permasalahan Keagenan di Pemerintah Daerah. Jurnal Akuntansi Pemerintah, Vol.2, No. 1

Hamzah, Ardi. 2008. Analisa Kinerja Keuangan terhadap Pertumbuhan Ekonomi, Pengangguran, dan Kemiskinan: Pendekatan Analisis Jalur (Studi pada 29 Kabupaten dan 9 Kota di Provonsi Jawa Timur Periode 2001 - 2006). Proceding Simposium Nasional Akuntansi XI. Pontianak

Hidayat, Agus. 2009. Pengaruh Dana Alokasi Umum, PDRB per kapita dan investasi, terhadap Pendapatan Asli Daerah Kabupaten- Kota di Provinsi Kalimantan Barat. Tesis.UGM

Hidayatullah, A Taufiq. 2011. Pengaruh PDRB, Jumlah Penduduk dan Inflasi terhadap Pendapatan Asli Daerah ( PAD ) Provinsi NTB tahun 2005 -2008. Universitas Islam Indonesia

Jensen, Michael C. dan Meckling William H. 1976. Theory of The Firm: Managerial Behaviour, Agency Costs and Ownership Structure. Journal of Financial Economics, October, 1976, V. 3, No. 4, pp. 305-360.

Jin, Jing and Heng-fu Zou. 2005. Fiscal Decentralization, Revenue and Expenditure Assignments, and Growth in China. Journal of Asian Economics.Central University of Finance and Economics, China.

Juoro, Umar. 2002. Otonomi Daerah dan Pemulihan Krisis Ekonomi. Google.com.

Jdih.cianjurkab.go.id

Julitawati, ebit dkk.2012. Pengaruh Pendapatan Asli Daerah dan Dana Perimbangan Terhadap Kinerja Keuangan Pemerintah Kabupaten/ Kota di Provinsi Aceh.

Kamus Besar Bahasa Indonesia. Jakarta: Pusat Bahasa Departemen Pendidikan Nasional, 2008, hal. 4.

Keputusan Menteri Dalam Negeri Nomor 29 Tahun 2002 tentang Anggaran Pendapatan dan Belanja Daerah.

Kifliansyah. 2004. Analisis Realisasi Anggaran Pendapatan Belanja Daerah. Bunga Rampai : Manajemen Keuangan Daerah.

Mahmudi. 2010. Analisa Laporan Keuangan Daerah. UPP STIM YKPN. Yogyakarta. Mardiasmo, 2002.Akuntansi Sektor Publik, Yogyakarta : Andi

Mohammad Riduansyah. 2003. "Kontribusi Pajak Daerah Dan Retribusi Daerah Terhadap Pendapatan Asli Daerah (PAD) dan Anggaran Pendapatan Dan Belanja Daerah (APBD) Guna Mendukung Pelaksanaan Otonomi Daerah (Studi Kasus Pemerintah Daerah Kota Bogor)" dalam http://journal.ui.ac.id diakses 12 Juni 2013.

Mustikarini, Widya Astuti dan Fitriasari Debby.2014.Pengaruh Karakteristik Pemerintah Daerah Dan Temuan Audit BPK Terhadap Kinerja Pemerintah Kabupaten/ Kota Di Indonesia Tahun Anggaran 2007.Simposium Nasional Akuntansi IV.Banjarmasin. dalam asp.trunojoyo.ac.id diakses 16 Februari 2015

Parmawati, Eka. 2010. Kausalitas Penerimaan, Belanja dan PDRB Kabupaten/ Kota di Indonesia. Universitas Diponegoro.

Patriati, Ratri.2010.Analisis Faktor - Faktor Yang Mempengaruhi Kinerja Keuangan Pemerintah Daerah di Jawa Tengah. UNS.

Peraturan Pemerintah Dalam Negeri Nomor 13 Tahun 2006 tentang Pedoman Pengelolaan Keuangan Daerah.

Peraturan Menteri Dalam Negeri Nomor 32 Tahun 2008 tentang Pedoman Penyusunan APBD Tahun Anggaran 2009. 
Peraturan Menteri Keuangan Nomor 174/PMK.07/2009 Tentang Peta Kapasitas Fiskal Daerah

Peraturan Menteri Keuangan Nomor 245/PMK.07/2010

Peraturan Menteri Keuangan Nomor 244/PMK.07/2011

Peraturan Menteri Keuangan Nomor 226/PMK.07/2012

Pratidina, Mega. Kinerja Keuangan Pemerintah Serta Tingkat Pendidikan, Tingkat Kemiskinan Di Kabupaten Blitar Tahun Anggaran 2008 -2010.

Putri, Nugrah Reksono. 2013. Analisis Pengaruh Karakteristik Pemerintah Daerah Terhadap Kinerja Keuangan Pemerintah Daerah ( Studi Empiris pada Pemerintah Kabupaten/ Kota Di Jawa Tengah). Tesis. Universitas Jenderal Soedirman.

Rahim, Syamsuri. 2008. Analisis Strategi Pengelolaan Keuangan Terhadap Kinerja Keuangan Daerah Kabupaten Takalar.

Rahmadi, Slamet ( 2011 ). Keterkaitan Penerimaan Daerah dan PDRB Propinsi Jambi ( Pendekatan simultan ). Jurnal Paradigma EkonomikaVol.1, No.4 Oktober 2011. Universitas Jambi

Rahmawati, Tyas Eka.2011. Analisis Laporan Keuangan Pemerintah Daerah untuk Penilaian Kinerja Keuangan.Unsoed.

Rozi.2010. Analisis PAD, Bagi Hasil Pajak dan Bukan Pajak, dan Sumbangan Daerah terhadap Total Penerimaan Daerah dengan perhitungan angka indeks desentralisasi fiskal ( studi kasus Kabupaten Jombang )

Rusmana Oman, Warsidi dan Afiah Nunuy.2013.Akuntansi Sektor Publik.Modul Kuliah dalam Omanrsm.blogspot.com

Saeli, La 2011.Analisis Efektivitas Pengelolaan Aset Pemerintah Daerah pada Dinas Pendapatan Pengelolaan Keuangan dan Aset Daerah Kota Bau - Bau.Tugas Akhir Program Magister. Universitas Terbuka

Santosa, Purbayu Budi. 2005. Analisis Pendapatan Asli Daerah (PAD) Dan FaktorFaktor Yang Mempengaruhinya Dalam Upaya Pelaksanaan Otonomi Daerah Di Kabupaten Kediri

Sekaran, Uma. 2006. Research Methods for Business : "Metodologi Penelitian untuk Bisnis. Edisi 4. Jakarta. Salemba Empat.

Sesotyaningsih, Mirna. 2012. Pengaruh leverage, Ukuran Legislatif, Intergovermental revenue, Pendapatan Pajak Daerah terhadap Kinerja Keuangan Pemerintah Daerah. Accounting Analysis Journal. Unnes

Simbolon, Bennyly Pangihutan Jouli. 2011. Pengaruh rasio efektivitas Pendapatan Asli Daerah (PAD), Dana Bagi Hasil ( DBH ), Dana Alokasi Umum ( DAU ), Dan Dana Alokasi Khusus Terhadap Tingkat Kemandirian Pemerintah Kabupaten / kota di Provinsi Sumatera

Speers, Kimberly. 2004. Performance Measurement in the Government of Alberta: Propaganda or Truth?

Subowo, Ari.2009.Tata Kelola Aset Daerah Dalam kerangka reformasi birokrasi, kasus di Provinsi Jawa Tengah.syukriy.wordpress.com/2009/04.

Sukirno, 1978."Pertumbuhan Ekonomi".Jakarta, Lembaga Penerbit Fakultas Ekonomi Universitas Indonesia, 1985

Sukirno, Sadono. 2004. Pengantar Ekonomi Makro, Edisi Ketiga. Raja Grafindo Persada. Jakarta.

Sularso, Havid dan Restianto Yanuar E. 2011. Pengaruh Kinerja Keuangan Terhadap Alokasi Belanja Modal dan Pertumbuhan Ekonomi Kabupaten/Kota Di Jawa Tengah. Media Riset Akuntansi. Vol 1 No 2 Agustus 2011 
Suliyanto, 2011. Ekonometrika Terapan : Teori\&Aplikasi dengan SPSS. Yogyakarta: CV. Andi.

Sutaryo.2012.Manajemen Aset Daerah. UNS. www.slideshare.net

Taha, Nathakumar dan Sisira. 2011. The Effect of Economic Growth on Taxation

Revenue: The Case of a Newly Industrialized Country .International Review of

Business Research Papers Vol. 7.No. 1. January 2011. Pp. 319 - 329. Malaysia

Undang-Undang Nomor 22 Tahun 1999 tentang Pemerintahan Daerah.

Undang - Undang No 17 tahun 2003 tentang Keuangan Negara

Undang - Undang No. 1 Tahun 2004 tentang Pembendaharaan Negara

Undang - Undang No 15 Tahun 2004 tentang Pemeriksaan Pengelolaan dan Tanggung Jawab Keuangan Negara yang menandai dimulainya reformasi di bidang keuangan negara

Undang-Undang Nomor 32 Tahun 2004 tentang Pemerintahan Daerah.

Undang-Undang Nomor 33 Tahun 2004 tentang Perimbangan Keuangan Antara Pemerintah Pusat dan Daerah.

Undang - Undang no 28 tahun 2009 tentang pajak daerah

Wafa, Sulfi. 2011. Pengaruh Pertumbuhan Ekonomi dan Jumlah Penduduk Terhadap Pendapatan Asli Daerah di Kabupaten Pasuruan. UIN Malang

Wahyuni, Nanik. 2012. Analisis Rasio Untuk Mengukur Kinerja Pengelolaan Keuangan Daerah Kota Malang diakses dalam ejournal.uin-malang.ac.id.

Wenny, Cherrya Dhin. 2012. Analisis Pengaruh Pendapatan Asli Daerah Terhadap Kinerja Keuangan Pada Pemerintah Kabupaten dan Kota di Propinsi Sumatera Selatan. Jurnal IImiah STIE MDP

Widiastuti, Ni Komang. 2013. Pengaruh sektor pariwisata terhadap kinerja keuangan daerah dan kesejahteraan masyarakat kabupaten/ kota di provinsi bali. Ejurnal Ekonomi dan Bisnis Universitas Udayana. Volume 02 No 05 Tahun 2013

www.wikipedia.com

www.bps.go.id

www.bpk.go.id

www.jateng.bps.go.id

www.ipb.ac.id

www.usu.ac.id

Widodo. 2004. "Analisis Rasio Keuangan Pada APBD Kabupaten Boyolali". Bunga Rampai Manajemen Keuangan Daerah: hal 281-29

Zhang, T. and H. Zou. 2001. "The Growt Impact of Intersectoral and Intergovernmental Allocation of Public expenditure: With Application to China and India". ChinaEconomic Review, No. 12, Hal. 58 - 81 